\title{
Recovery after experimental cutting and burning in three shrub communities with different dominant species
}

\author{
L. Calvo*, R. Tárrega, E. Luis, L. Valbuena and E. Marcos \\ Area of Ecology, Faculty of Biology, University of León, 24071 León, Spain; *Author for correspondence \\ (e-mail:deglcg@unileon.es; fax: +34-987-291409)
}

Received 15 March 2004; accepted in revised form 15 December 2004

Key words: Calluna vulgaris, Cistus ladanifer, Community recovery, Disturbances, Erica australis, Shrublands

\begin{abstract}
The aim of this study is to compare the recovery dynamics in three shrub communities subjected to experimental burning and cutting, and situated on an altitudinal gradient. Climatic features are different in each area, but all had the common characteristic of very homogeneous vegetation cover before the disturbances, with only one shrub species clearly dominant, a different taxon in each area, and with different regeneration strategies. The first area was a heathland dominated by Calluna vulgaris, situated at an altitude of $1600 \mathrm{~m}$, with a continental climate (mean annual precipitation $1320 \mathrm{~mm}$ ). The second area was a heathland dominated by Erica australis, located at an altitude of $1000 \mathrm{~m}$ (mean annual precipitation $840 \mathrm{~mm}$ ). The third area was a Cistus ladanifer shrubland, located at $900 \mathrm{~m}$ altitude, with a Mediterranean climate similar to that of the previous area, but with lower mean annual precipitation $(470 \mathrm{~mm})$. Erica australis recovers by vegetative resprouting, but Cistus ladanifer is an obligate seeder, as is Calluna vulgaris in these areas. Each experimental disturbance was carried out over $100 \mathrm{~m}^{2}$ in each area. Post-fire recovery is faster in Cistus ladanifer: 2 years after burning there was $40 \%$ cover vs. less than $20 \%$ in the other two species. However, recovery after cutting was similar for Cistus ladanifer and Erica australis. Calluna vulgaris recovers very slowly, with cover values below $20 \%$ even 10 years after both disturbances. Cover of dominant shrub species is negatively correlated with cover of herbaceous species. So different recovery of dominant species lead a different community dynamic in each area.
\end{abstract}

\section{Introduction}

Communities in the Mediterranean Basin, as they exist at present, are a result of human activity to a great extent (Naveh and Lieberman 1990; Pausas 1999; Luis-Calabuig et al. 2000; Trabaud 2000). This has resulted in a gradual replacement of the original forest by shrub communities. In addition, these communities have spread more and more in the last few decades as a result of pasture and cultivation set-aside, with the consequent onset of secondary succession processes. Most of these ecosystems show great resilience to disturbance and usually recover by an autosuccession process (Hanes 1971; Naveh 1975, 1999; Dell et al. 1986; Trabaud 1987; Casal et al. 1990; Mazzoleni and Esposito 1993; Luis-Calabuig et al. 2000). In the province of León, as in most of Spain, shrublands are very abundant, covering $33 \%$ of the surface area (Ministerio de Agricultura 1984). Fire is one of the common management methods used by shepherds to reduce the proliferation of woody 
species and maintain pastures, both in the mountains (higher than $1500 \mathrm{~m}$ above sea level) and on the plains $(800-1000 \mathrm{~m})$. The second most common type of disturbance is cutting in order to obtain domestic fuel and fertilizers, for example (Casal 1985; Calvo et al. 2002a). Most of the shrub species in these communities recover by vegetative resprout, but others, like Cistus species, are considered obligate seeders, with seeds whose germination is stimulated by heat (Valbuena et al. 1992; Trabaud 2000).

The response of the communities to disturbance partly depends on the type of disturbance and the adaptive traits of the species present. Climatic conditions also have a huge influence on the speed of recovery. The aim of this study is to compare the recovery dynamics in three shrub communities submitted to two experimental disturbances (burning and cutting) and situated on an altitudinal gradient $(900-1600 \mathrm{~m})$. Climatic features are different in each area, but all of them had the common characteristic of being very homogeneous before disturbance, with only one shrub species clearly dominant, although a different one in each area (Calluna vulgaris, Erica australis and Cistus ladanifer). These communities have composed by three different shrub species with different recovery response: Erica australis is a facultative resprouter and recovers mainly by vegetative resprouting (Calvo et al. 1998, 2002a); while, Cistus ladanifer is an obligate seeder (LuisCalabuig et al. 2000; Tárrega et al. 2001) as is Calluna vulgaris in these areas (Calvo et al. 2002b). Knowledge of the recovery dynamics of each community in relation to the type of disturbance is essential for suitable landscape management.

\section{Materials and methods}

Three shrub areas situated in the province of León (NW Spain) were chosen for the study. All had a very homogeneous structure, the dominant shrub plants being more than 20 years old. They were secondary stages of succession, which started as a consequence of the abandonment of old fields or pastures. The dominant species was different in each area, as were the soils (Mapa de Suelos de Castilla y León 1988) and climatic features (Ministerio de Agricultura 1980).
The first zone is a Calluna vulgaris heathland situated in the San Isidro mountain pass, at an altitude of $1600 \mathrm{~m}$, with no slope. Its MTU coordinates of 30TUN072695. The soils are Leptosols and the climate is continental (mean annual precipitation is $1320 \mathrm{~mm}$, without a dry period, mean annual temperature is $5.5^{\circ} \mathrm{C}$, mean minimum in the coldest month is $-3.5^{\circ} \mathrm{C}$ and mean maximum in the warmest month is $18.5^{\circ} \mathrm{C}$ ). The dominant species, Calluna vulgaris, had a mean cover greater than $80 \%$; other woody species present were Erica tetralix, Erica australis and Vaccinium myrtillus (mean cover less than 5\%). Herbaceous species were not abundant (total cover less than 5\%).

The second zone, is an Erica australis heathland situated at an altitude of about $1000 \mathrm{~m}$, with no slope. Its MTU coordinates 30TUN248336. The soils are Humic Cambisols and the climate is cool temperate Mediterranean (mean annual precipitation is $840 \mathrm{~mm}$, with a dry period in July and August, mean annual temperature is $10.9^{\circ} \mathrm{C}$, mean minimum in the coldest month is $-1.1{ }^{\circ} \mathrm{C}$ and mean maximum in the warmest month is $\left.26.9^{\circ} \mathrm{C}\right)$. Erica australis had a mean cover higher than $75 \%$, other woody species (Calluna vulgaris, Halimium alyssoides, Halimium umbellatum and Thymus zygis) had less than $1 \%$ cover. Herbaceous species were also less than $1 \%$.

The third zone, is a Cistus ladanifer shrubland situated at an altitude of about $900 \mathrm{~m}$, with no slope. Its MTU coordinates 29TQG3929. The soils are Regosols and the climate is cool temperate Mediterranean (mean annual precipitation is $470 \mathrm{~mm}$, with a dry period in July and August, mean annual temperature is $10.5^{\circ} \mathrm{C}$, mean minimum in the coldest month is $-1.0^{\circ} \mathrm{C}$ and mean maximum in the warmest month is $26.5^{\circ} \mathrm{C}$ ). The dominant species was Cistus ladanifer with mean cover greater than $70 \%$. The other woody species present, Lavandula stoechas and Halimium umbellatum, were less abundant (less than 5\%). Herbaceous species were scarce with mean cover below $4 \%$.

The experimental disturbances were carried out in two $100 \mathrm{~m}^{2}$ plots in each area. One of the plots was burned in summer simulating a wildfire, in the other all the woody aboveground biomass was cut to ground level (July 1985 for cutting and July 1986 for burning in the Calluna community, July 1985 for both disturbances in the Erica community, and July 1989 for both disturbances in the 
Cistus community). To record changes in the plant communities, 5 quadrats $\left(1 \mathrm{~m}^{2}\right.$ each) were randomly chosen during the first sampling and these were sampled annually in June for 10 years (data from the first year after disturbances were not available for the Erica community nor for the first year after cutting in the Calluna community). The cover in vertical projection of each species was visually estimated.

A three factor ANOVA (zone, disturbance and time, repeated measure) were carried out in order to compare total cover, dominant species cover and richness $/ \mathrm{m}^{2}$ values, distinguishing woody species, perennial and annual herbaceous species. Previously the sampling normality was checked by the David test (David et al. 1954) and the homogeneity of the variances by the Cochran test (Cochran 1941).

Temporal trends in woody, annual and perennial herbaceous species cover were analysed by testing the curve fitting to the more usual growth curves. The mean cover values of the species in the 5 quadrats in each plot and sampling period, were used in these analysis.

In order to establish if there were general trends in the post-disturbance recovery in the three shrublands, a principal components analysis was carried out considering 7 variables: woody, annual and perennial herbaceous species richness (species number), and woody, annual and perennial herbaceous species cover, as well as cover of the dominant species in the pre-disturbance situation.

\section{Results}

Total cover tends to increase over time, although with oscillations (Figure 1). The lowest values are observed in the first 2 years, except in the cut Cistus plot, with cover of over $70 \%$ in the first year. The highest cover values usually appear in the Calluna community from the third year, particularly in the cut plot, with values of over $100 \%$ due to strata superposition. Significant differences in total cover $(F=13.95 ; p<0.05)$ between burnt and cut plot were only found in the Calluna community. The contribution of the dominant species before the disturbances to the post-disturbance total cover value is much lower in the Calluna community than in the other two communities and it is significant lower $(F=13$; $p<0.05)$ in the cut plot than in the burned plot. In contrast, the contribution of the Erica species, with intermediate recovery characteristics, to total cover in this community is usually greater in the cut plot than in the burned one, especially in the first few years, but these differences are not significant $(F=0.17 ; p>0.05)$. On the other hand, Cistus represents almost $50 \%$ of total cover 1 year after burning and more than $70 \%$ from the second year; the proportion in the cut plot is somewhat lower in the first few years, but is more than $80 \%$ of the total in both plots from the sixth year. So, there are a different recovery dynamic among the three communities with significant differences in total cover between zones $(F=4.48 ; p<0.05)$ and with significant interaction between the factor zone and the factor time $(F=2.09 ; p<0.05)$ in the tree way ANOVA.

The cover of woody species tends to increase in the three burned plots, with a significant fitting $(p>0.99)$ from a logarithmic curve (Figure 2a). However, recovery is more rapid in the plot dominated by Cistus, with values close to $30 \%$ one-year post-fire and above $40 \%$ from the second year. In contrast, in the Calluna plot woody cover is below $1 \%$ one-year post-fire and shows the greatest annual oscillations. The Erica plot has intermediate characteristics, with $20 \%$ cover in the second year and values of approximately $40 \%$ from the fourth year. Perennial herbs show no clear temporal tendency in the two plots with a Mediterranean climate, although their cover is lower in the Cistus plot. The perennial herbs in the Calluna plot are also abundant and tend to increase in cover over time, with a significant fitting $(p>0.95)$ to a logarithmic type curve. In addition, interannual variation is observed which, in some years, is opposite to that of the woody species. In this plot the annual species show no temporal trend, with cover below $1 \%$ in the first 2 years and close to $40 \%$ in the third. However, their cover is always below $20 \%$ in the other two plots and, moreover, tends to diminish with a significant logarithmic fitting $(p>0.99)$ in the Cistus plot, while there is a linear fitting in the Erica plot $(p>0.95)$.

Woody species show a similar tendency in the cut plots to that observed in the burned plots (Figure 2b). Only in the Calluna community cut plot there is a significant fitting $(p>0.99)$ towards a linear regression pattern, indicating that cover 
Calluna Community
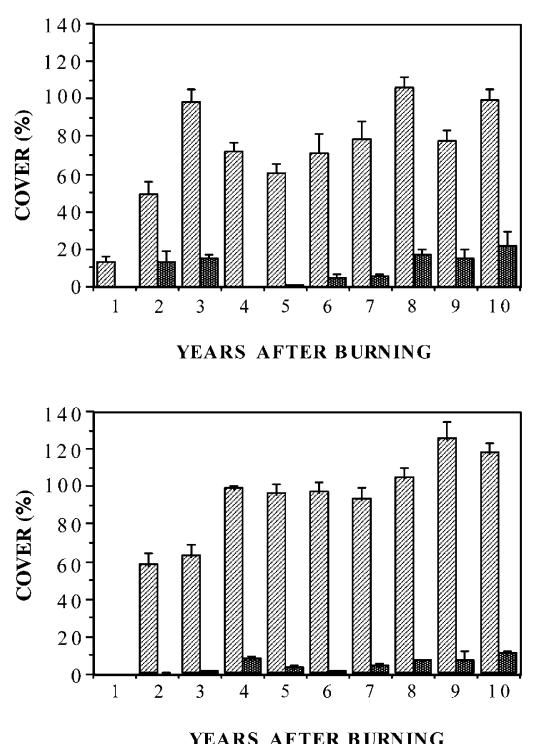

Erica Community
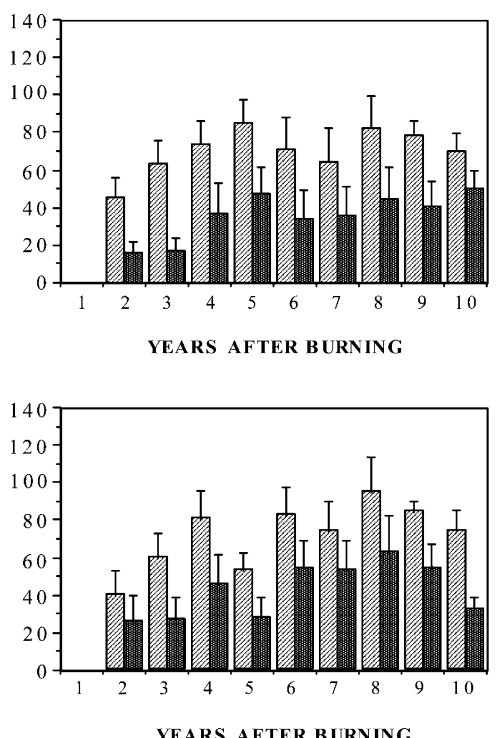

YEARS AFTER B URNING
Cistus Community
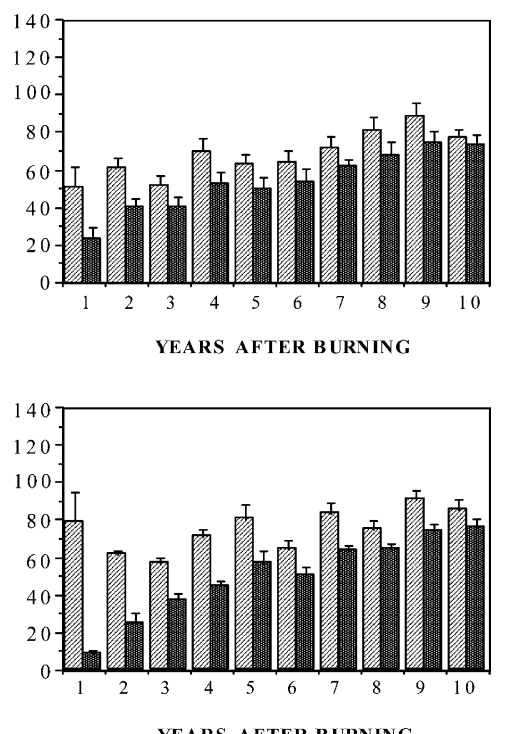

Total Cover

Dominant Species Cover

Figure 1. Changes in total plant cover and cover of the dominant species (mean values and standard error) in each community during the study period.

continues to increase and that there is still no detectable tendency towards stabilization after 10 years. In the last years the highest woody cover is recorded in the cut Cistus community, as in the burned plots. There are more interannual variations in the cut plots of Calluna and Erica than with Cistus. Perennial herbs are more abundant in the Calluna community (between 30 and $65 \%$ cover) and do not show any temporal tendency. They do not reach $30 \%$ in the other two communities, although they come close to this value in the Erica community in some years. Their cover in the Cistus community does not reach $20 \%$ in the first year and tends to decrease in the following years, with a significant fitting to a logarithmic curve with a negative slope $(p>0.99)$. Annual cover is usually below $5 \%$ in the Calluna and Erica plots but very abundant in the Cistus plot in the first 2 years with a marked decrease afterwards.

Mean species richness by square metres does not present any great variations in the Calluna community, with the lowest value 1 year after burning $(<5$ species) and the highest in the tenth year ( $>12$ species); variation in the cut plot is even lower than 9 species throught study period (Figure 3). This community has the significant lowest number of annual herbs $(F=10.41$; $p<0.05)$ and in the first years the lowest species richness of the three communities. In each year, the highest numbers of species were perennial herbs. Mean species richness in the Erica community is greater than in Calluna community, reaching its maximum value in the fifth year in the burned plot (17 species) and its minimum in the tenth year (8 species); richness in the cut plot oscillates between 10 and 14 species except in the seventh year, when only 7 were recorded. This community has the significant highest number of perennial herbs $(F=47.39 ; p<0.05)$ but, in addition, has a greater diversity of annual species in comparison with the Calluna community. A temporal tendency in species richness is only observed in the Cistus community, with higher values in the first 2 years after the disturbances, whilst there are interannual variations without any clear tendency in later years. Woody species $(F=20.74 ; p<0.05)$, perennial herbs $(F=7.74 ; p<0.05)$ and annual species richness $(F=31.59 ; p<0.05)$ are significant greater in the cut plot than in the burned one in 
(a) Calluna Community
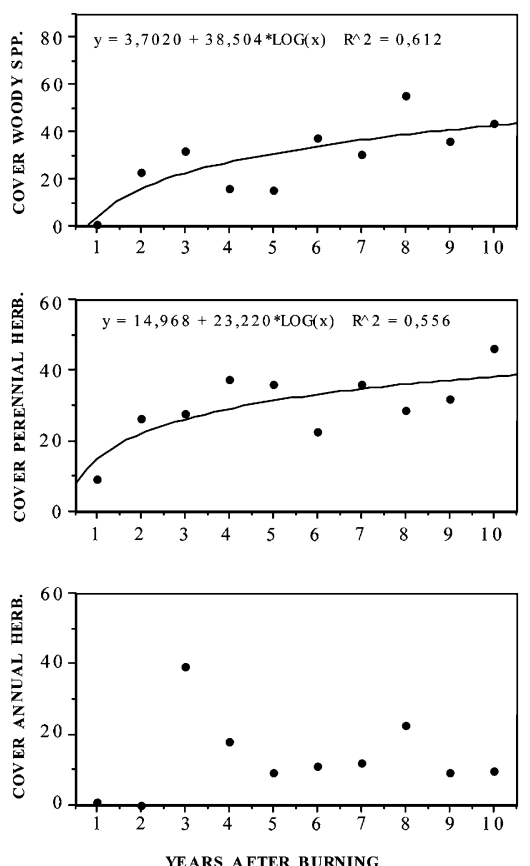

(b)
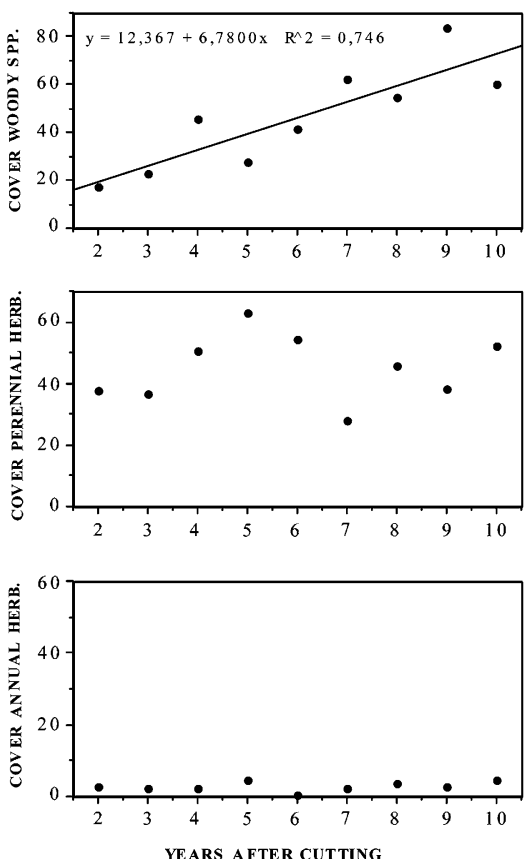

Erica Community
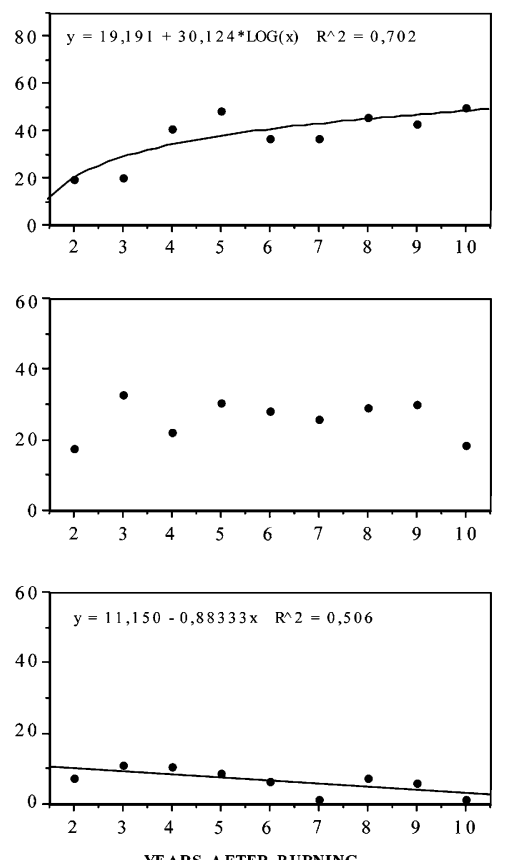

Erica Community
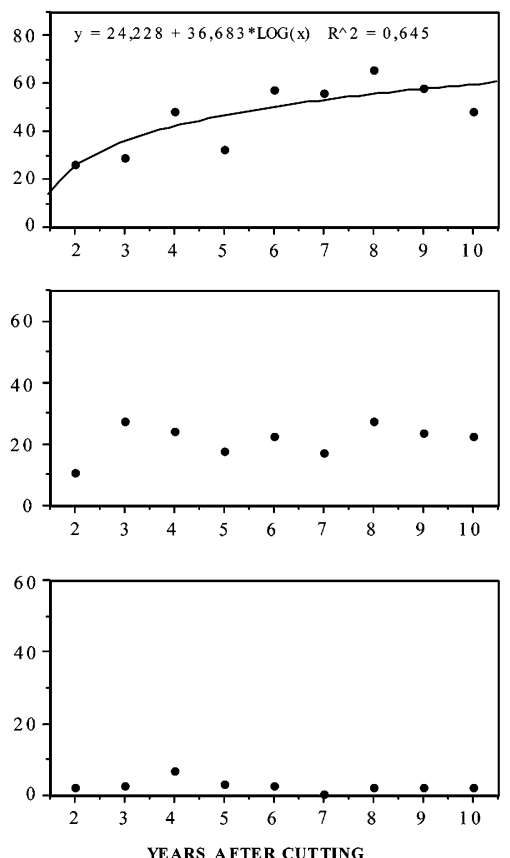

Cistus Community
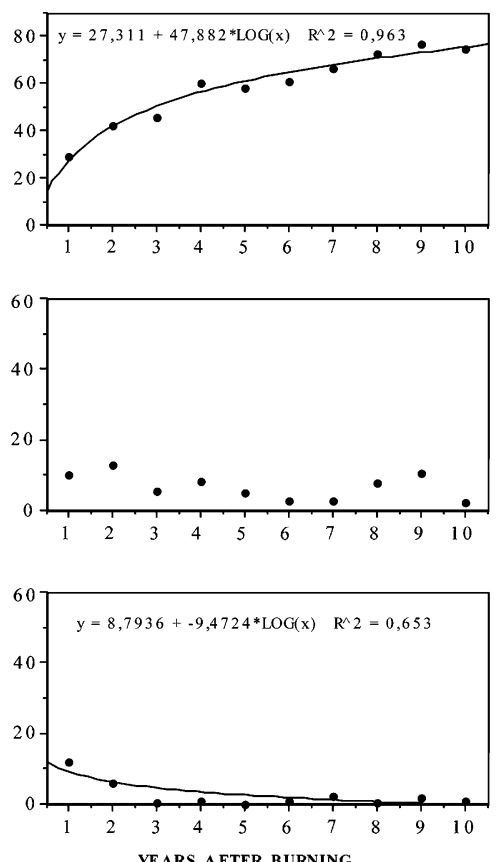

Cistus Community
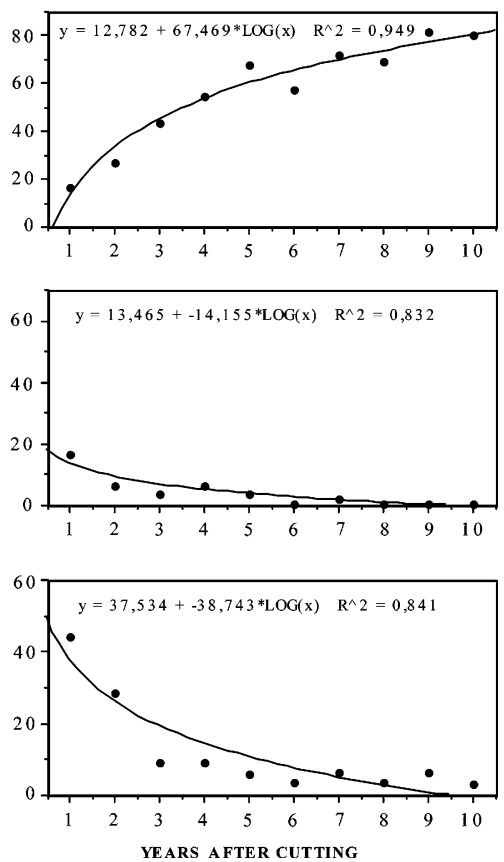

Figure 2. (a) Cover values for woody, perennial herbaceous and annual species in the burned plots during the study period. Curve fitting is only included when the fit is significant $(>95 \%)$. (b) Cover values for woody, perennial herbaceous and annual species in the cut plots during the study period. Curve fitting is only included when the fit is significant $(>95 \%)$. 
Calluna Community
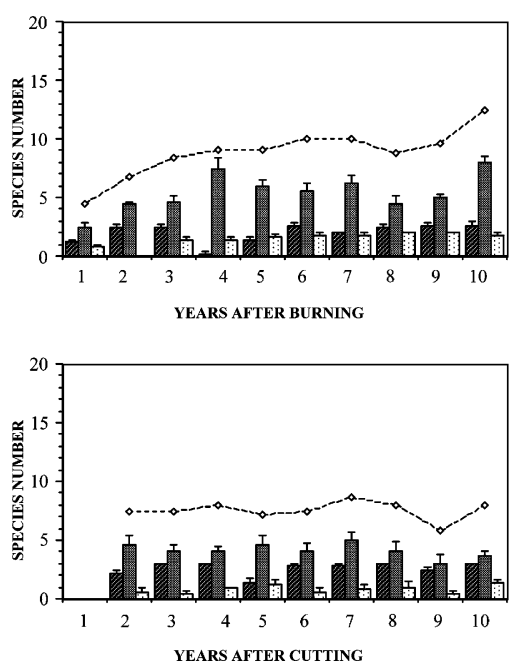

Erica Community
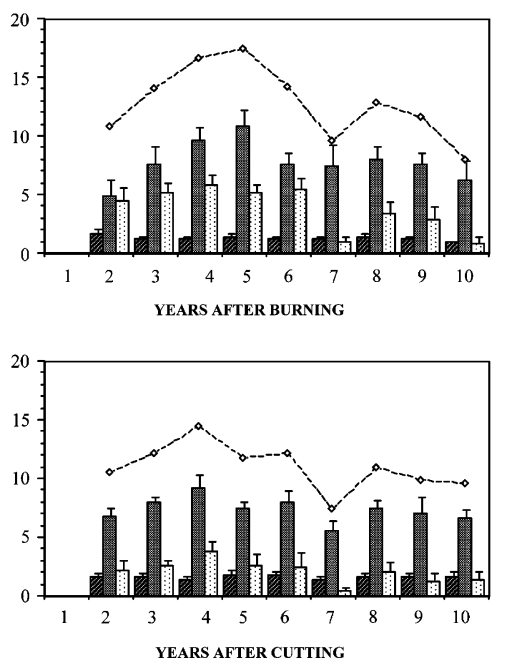

Cistus Community
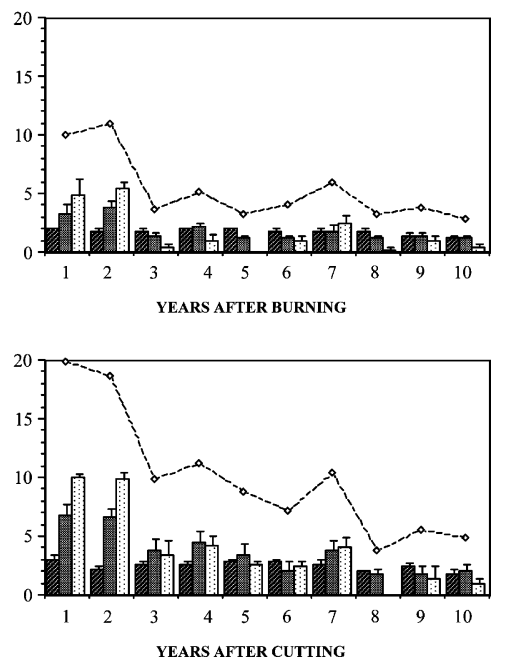

Figure 3. Changes in mean species richness $/ \mathrm{m}^{2}$ and standard error (total, woody, perennial herbaceous and annual species) in each community during the study period.

Cistus community. Annual species usually exceed the number of perennial herbs in this community.

Two principal component analyses (PCA) were carried out for the global comparison of results, one using data from the burned plots of each community and the other using the data from the cut plots. In the PCA data from the burned plots, the first axis (explained variance $=46 \%$ ) separates the cover of herbaceous species, with positive values, from the cover of woody species and the pre-disturbance dominant species, both with negative values (Figure 4a). Pearson' correlation index is negatively significant (Table 1) between dominant species cover and perennial and annual herbaceous cover. The second axis (explained variance $=22 \%$ ) separates richness of woody species with positive values, and richness of annuals with negative values. As regards the samples, the three community types are separated, with the Calluna plot situated in the first quadrant because of its greater richness in woody species and cover of annual species, lower cover of woody species and especially lower cover of the pre-fire dominant species. The records from the Erica plot and the first two from the Cistus plot are associated with greater richness in both annual and perennial herbaceous species. The rest of the records from the Cistus plot are towards the negative part of the first axis because of their greater cover of woody species and, specifically, of Cistus ladanifer. Except in the Cistus plot, where the first two samplings are widely separated from the rest and more similar to those of the Erica plot, no temporal tendency is shown.

In the PCA corresponding to the samples from the cut plots, the first axis (explained variance $=38 \%$ ) separates cover of the dominant species in the initial situation and cover and number of woody species in the positive axis from cover and number of perennial herbs with negative values. The second axis (explained variance $=34 \%$ ) separates the cover and number of annual species, situated on the positive axis, from woody and perennial herb cover on the negative side. A significant negative correlation (Table 2) is observed between dominant species cover and herbaceous species cover. The woody species number is significant negatively correlated with the perennials herbaceous cover and number. The location of the samples in the plane defined by these two axes separates the communities, with Erica in an intermediate position between the 

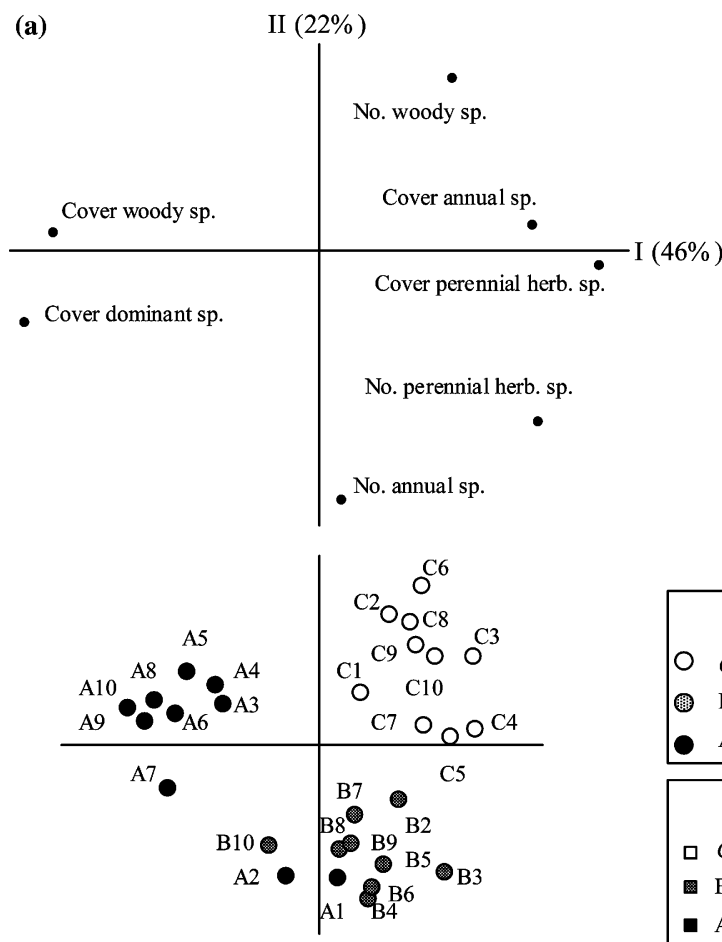
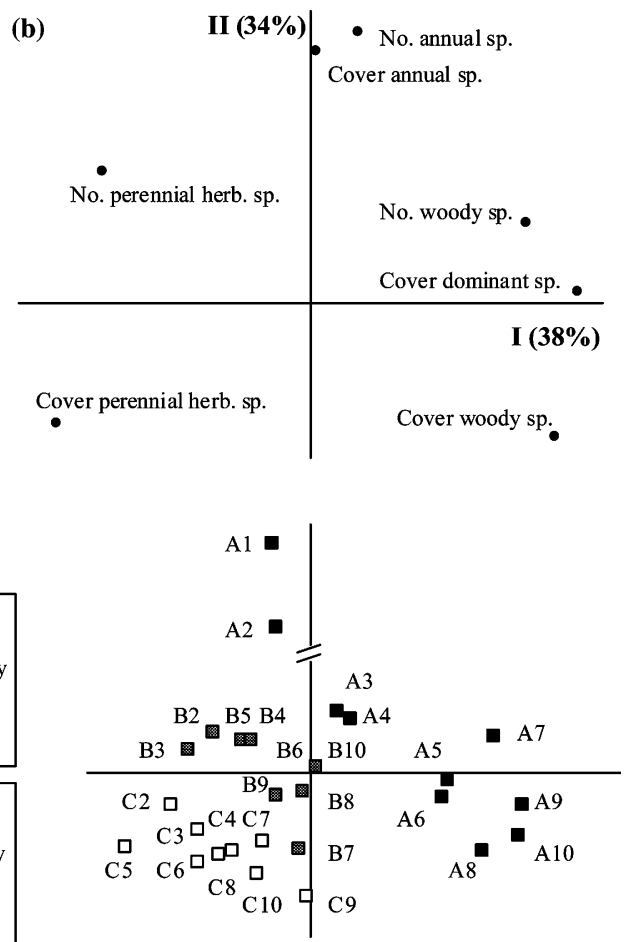

Figure 4. (a) Location of variables and samples in the plane defined by the two first axes of the principal components analysis carried out with data from the burned plots. (b) Location of variables and samples in the plane defined by the two first axes of the principal components analysis carried out with data from the cut plots. (Numbers after the letters representing each community indicate years after experimental disturbances.)

Table 1. Correlation matrix between the variables used in the PCA analysis of the burned plots.

\begin{tabular}{|c|c|c|c|c|c|c|}
\hline & No. W spp. & No. P spp. & No. A spp. & W cover & $\mathrm{P}$ cover & A cover \\
\hline \multicolumn{7}{|l|}{ No. Woody spp. } \\
\hline No. Perennial herb spp. & 0.02 & & & & & \\
\hline No. Annual spp. & -0.28 & $0.44^{*}$ & & & & \\
\hline Woody spp. cover & -0.10 & $-0.45^{*}$ & -0.10 & & & \\
\hline Perennial herb spp. cover & 0.34 & $0.71^{*}$ & -0.02 & $-0.51^{*}$ & & \\
\hline Annual spp. cover & 0.30 & 0.28 & 0.06 & -0.32 & $0.51 *$ & \\
\hline Pre-fire dominant sp. cover & $-0.40^{*}$ & -0.35 & 0.11 & $0.89 *$ & $-0.63^{*}$ & $-0.51^{*}$ \\
\hline
\end{tabular}

* Marked correlations are significant at $p<0.05$.

Table 2. Correlation matrix between the variables used in the PCA analysis of the cut plots.

\begin{tabular}{|c|c|c|c|c|c|c|}
\hline & No. W spp. & No. P spp. & No. A spp. & W cover & $\mathrm{P}$ cover & A cover \\
\hline \multicolumn{7}{|l|}{ No. Woody spp. } \\
\hline No. Perennial herb spp. & $-0.55^{*}$ & & & & & \\
\hline No. Annual spp. & 0.25 & $0.41^{*}$ & & & & \\
\hline Woody spp. cover & 0.26 & $-0.56^{*}$ & -0.27 & & & \\
\hline Perennial herb spp. cover & $-0.44 *$ & 0.16 & $-0.51^{*}$ & -0.30 & & \\
\hline Annual spp. cover & $0.40^{*}$ & 0.19 & $0.77^{*}$ & -0.36 & -0.24 & \\
\hline Pre-fire dominant sp. cover & 0.22 & -0.23 & 0.22 & $0.61 *$ & $-0.76^{*}$ & -0.12 \\
\hline
\end{tabular}

*Marked correlations are significant at $p<0.05$. 
other two. The samples from the Calluna plot are associated with greater perennial herb cover, and low cover and number of annual species, as well as low recovery rates for Calluna vulgaris. In the Cistus plot a temporal tendency can still be observed, with the samples from the first 2 years after cutting associated with high values for annual species richness and cover, while those from the last years show greater richness and cover of woody species, in particular Cistus ladanifer.

\section{Discussion}

The recovery response of each of the three dominant woody species in the three communities studied is different, depending on their adaptive traits. Many authors have indicated the advantages of vegetative resprouting in comparison with germination for post-fire recovery (Keeley 1986; Trabaud 1987; Terradas 1996; Naveh 1999). Resprouting can occur immediately after a fire, taking advantage of the nutrients and water accumulated in the roots, that implies a substantial pre-fire allocation of the resources acquired by the plant to stored reserves (Bond and van Wilgen 1996; Hodgkinson 1998). However, in the study zones, recovery is faster in Cistus ladanifer, an obligate seeder, than in Erica australis, a facultative resprouter, especially in the burned plots. Heat stimulates the germination of Cistus ladanifer seeds (Valbuena et al. 1992; Trabaud 2000), which explains its rapid post-fire recovery. However, Cistus ladanifer cover is also greater than, or at least similar to, that of Erica australis in the cut plots after the first years. Erica australis is characterized by rapid resprouting after disturbances and it only has to recover its aboveground biomass, since it starts from an intact root system, this gives it an advantage over seeder species. However, seeders can spread and colonize new microsites, whereas resprouters are restricted to the micro-sites previously occupied. On the other hand, Calluna vulgaris, which is an obligate seeder in these areas (Vera and Obeso 1995; Calvo et al. 2002b), is the slowest to recover. A good initial response was observed in this species after the fire, because heat stimulates its germination (GonzalezRabanal and Casal 1995; Webb 1998; Valbuena et al. 2000). However, there was seedling mortality in the fourth year, probably due to the long period during which this species was under snow (Calvo et al. 2002b). Vegetation dynamics in heathlands seem to depend on the interaction between species attributes and the climatic conditions in the area (Clement and Touffet 1981). Germination is not stimulated by cutting and Calluna vulgaris cover is lower in this plot.

A comparison of the responses of the dominant woody species did not indicate differences between the burned and cut plots, except in the first years. A great ability to resprout after fire is a recognized characteristic of many Mediterranean species (Canadell and Zedler 1995; Bond and van Wilgen 1996). However, there is less data about this response after cutting or after clearing (Lloret and Vilà 1997). Erica australis has a lignotuber, which allows it to resprout actively, but this resprouting capacity is similar after both burning and cutting. A similar observation was made by Cruz and Moreno (2001), who consider that the lignotuber of this species is not a specific adaptation to fire, but rather to summer drought and low temperatures in winter. Similarly, Cistus ladanifer do not behave like a fire-dependent species; rapid recovery after both cutting and burning was also observed by Trabaud (1995), who considers the survival method of Cistus spp. as an adaptation to unpredictable disturbances and environmental constraints rather than an adaptation to repeated burning.

Many authors have observed an increase in the richness and abundance of herbs in the first years after disturbances (Trabaud and Lepart 1980; Mallik and Gimingham 1983; Casal et al. 1990; Clement and Touffet 1990; Bond and van Wilgen 1996; Cowling et al. 1996; Naveh 1999; Ne'eman and Goubitz 2000; Degn 2001), but it is usually restricted to the first 5 years. The speed of the dominant species recover, in the studied plots, conditions the dynamics of the plant community to a great extent. The slower recovery of Calluna vulgaris allows other woody species, like Vaccinium myrtillus and Erica tetralix, dominant throughout the study period in the burned and cut plots, respectively, to spread (Calvo et al. 2002b). It also allows greater perennial herb cover. Annual species cover is low, except in the burned plot in some years, and in these cases is due to a single species: Aira caryophyllea (Calvo et al. 2002b). In contrast, the rapid recovery of Cistus ladanifer, especially after burning, restricts the proliferation 
of other species, so herbs have low abundance. A comparison of cutting and burning indicates that patterns of proliferation in herbs are not similar in the three communities studied, but are inversely correlated to the recovery of the dominant species after each type of disturbance. There is a greater abundance of herbs (in terms of number of species as well as cover) in the cut plot than in the burned plot in the Cistus community. The opposite occurs in the Erica community with a higher number of herbaceous species in the burned plot. In the Calluna community herbs are abundant during the 10 years of study period in both plots. These results do not completely agree with observations by other authors, who record greater herb diversity after burning (Casal et al. 1984; Naveh 1990).

It has been suggested that the increase of herbs can inhibit the recovery of the dominant woody species when this occurs by germination. Some authors consider that burning is more appropriate for regenerating Calluna heathlands because sodcutting may lead to an unfavourable ratio between Calluna and grass seedlings at the start of secondary succession (Aerts 1993; Bruggink 1993). In the study area, herbs are also abundant after burning and may be partly responsible for the slower recovery of Calluna vulgaris. However, the high herb cover value in the cut plot of the Cistus community in the first 2 years does not seem to have a negative effect on the recovery of the dominant woody species. This contrasts with observations by Legrand (1993), who found that competition with the herbaceous layer had a negative effect on the recovery of other Cistus species.

With reference to different life forms, annual species have been associated with warmer conditions and a more arid summer (Archibold 1995). This seems to agree with what was observed in the study areas, above all in terms of species richness, with the greatest annual richness in the Cistus community with a Mediterranean climate, and the lowest in the Calluna community, with a continental climate. In terms of cover, the relationship with climatic conditions is only observed in the cut plots, with greater cover in the Cistus community and practically none in the other two. In the burned plots the patterns are not so clear. These patterns are confirmed in the PCA, where the results from the first 2 years after cutting and burning in the Cistus community are associated with a greater number of annuals, and also higher cover of Cistus in the cut plots. Therefore, in addition to adaptive traits, climatic conditions are important to recovery of the dominant species and the interaction of both aspects determines the dynamics of these communities. The recovery of Calluna vulgaris is slowed by low temperatures, with perennial herbs dominating, whilst interannual variations probably result in the fluctuations in the cover of Aira caryophyllea, the only annual herb abundant in the area (Calvo et al. 2002b). The harshest summer drought in the Cistus community could favour annuals in the first 2 years and drastically limit the proliferation of herbs in this community when they have to compete with the dominant woody species. The Erica community presents an intermediate situation.

Recovery occurs by autosuccession in the Cistus and Erica communities (Tárrega et al. 2001; Calvo et al. 2002a). However, after 10 years the Calluna community has not attained a situation similar to that existing before the disturbances (Calvo et al. 2002b). Similar results were found by Bond and van Wilgen (1996), who indicate that autosuccession is common in most Mediterranean shrubs, whilst post-fire succession in Calluna heathlands is complicated by several factors, such as the composition of pre-fire community and weather patterns in the post-fire period. These factors can produce multiple pathways of succession and very different post-burn communities.

This paper shows the importance of the adaptive mechanisms of the dominant species in post-disturbance plant dynamics. In the three geographically close communities studied (no more than $100 \mathrm{~km}$ apart in a straight line), different patterns are observed between the Atlantic shrubland and the drier Mediterranean habitat (Cistus community), with the Erica community presenting intermediate behaviour. Knowledge about the individual response of each type of community to each disturbance is a basic first step towards correct landscape management in these areas, depending on the aims (eliminating or maintaining woody species, favouring herb biodiversity, etc.).

\section{References}

Aerts R. 1993. Competition between dominant plant species in heathlands. In: Aerts R. and Heil G.W. (eds), Heathlands: Patterns and Processes in a Changing Environment. Kluwer 
Academic Publishers, Dordretcht, The Netherlands, pp. 125151.

Archibold O.W. 1995. Ecology of World Vegetation. Chapman \& Hall, London.

Bond W.J. and van Wilgen B.W. 1996. Fire and Plants. Chapman \& Hall, London.

Bruggink M. 1993. Seed bank, germination and establishment of ericaeous and gramineous species in heathlands. In: Aerts R. and Heil G.W. (eds), Heathlands: Patterns and Processes in a Changing Environment. Kluwer Academic Publishers, Dordretcht, The Netherlands, pp. 153-180.

Calvo L., Tárrega R. and Luis E. 1998. Space-time distribution patterns of Erica australis L. subsp. aragonensis (Willk) after experimental burning, cutting and ploughing. Plant Ecol. 137: $1-12$.

Calvo L., Tárrega R. and Luis E. 2002a. Secondary succession after perturbations in a shrubland community. Acta Oecol. 23: 393-404

Calvo L., Tárrega R. and Luis E. 2002b. Regeneration patterns in a Calluna vulgaris heathland in the Cantabrian Mountains (NW Spain): effects of burning, cutting and ploughing. Acta Oecol. 23: 81-90.

Canadell J. and Zedler P.H. 1995. Underground structures of woody plants in Mediterranean ecosystems of Australia, California and Chile. In: Fox M., Arroyo M.K. and Zedler P.H. (eds), Convergent Evolution in Mediterranean Ecosystems of Australia, California and Chile. Springer-Verlag, Berlin, pp. 177-210.

Casal M. 1985. Cambios en la vegetación del matorral tras incendio en Galicia. In: Estudios sobre prevención y efectos ecológicos de los incendios forestales. Ministerio de Agricultura, Pesca y Alimentación, Madrid, pp. 93-101.

Casal M., Basanta M. and García-Novo F. 1984. La regeneración de los montes incendiados en Galicia. Monografías de la Universidad de Santiago, 99. Ed. Univ. de Santiago.

Casal M., Basanta M., González F., Montero R., Pereiras J. and Puentes A. 1990. Post-fire dynamics in experimental plots of shrubland ecosystems in Galicia NW Spain. In: Goldamer J.G. and Jenkins M.J. (eds), Fire in Ecosystem Dynamics. SPB Academic Publishing, The Hague, pp. 33-42.

Clement B. and Touffet J. 1981. Vegetation dynamics in Brittany heathlands after fire. Vegetatio 46: 157-166.

Clement B. and Touffet J. 1990. Plant strategies and secondary succession on Brittany heathlands after several fires. J. Veg. Sci. 1: 195-202.

Cochran W.G. 1941. The distribution of the largest of a set of estimated variances as a fraction of their total. Ann. Eugen. (Lond.) 11: 47-61.

Cowling R.M., Rundel P.W., Lamont B.B., Arroyo M.K. and Arianoutsou M. 1996. Plant diversity in Mediterranean climate regions. Tree 11(9): 362-366.

Cruz A. and Moreno J.M. 2001. Seasonal course of total nonstructural carbohydrates in the lignotuberous Mediterraneantype shrub Erica australis. Oecologia 128: 343-350.

David H.A., Hartley H.O. and Pearson E.S. 1954. The distribution of the ratio, in a single normal sample of range to standard deviation. Biometrika 41: 482-493.

Degn H.J. 2001. Succession from farmland to heathland: a case for conservation of nature and historic farming methods. Biol. Conserv. 97: 319-330.
Dell B., Hopkins A.J.M. and Lamont B.B. (eds) 1986. Resilience in Mediterranean-type Ecosystems. Dr. W. Junk Publishers, Dordrecht.

Gonzalez-Rabanal F. and Casal M. 1995. Effects of high temperatures and ash on germination of ten species from gorse shrubland. Vegetatio 116: 123-131.

Hanes T.L. 1971. Succession after fire in the chaparral of southern California. Ecol. Monogr. 41: 27-52.

Hodgkinson K.C. 1998. Sprouting success of shrubs after fire: height-dependent relationships for different strategies. Oecologia 115: 64-72.

Keeley J.E. 1986. Resilience of mediterranean shrub communities to fires. In: Dell B., Hopkins A.J.M. and Lamont B.B. (eds), Resilience of Mediterranean-Type Ecosystems. Dr. W. Junk Publishers, Dordrecht, pp. 95-112.

Legrand C. 1993. Regeneration of two Cistus species after prescribed burning. In: Trabaud L. and Prodon R. (eds), Fire in Mediterranean Ecosystems. ECSC-EEC-EAEC, Brussels, pp. 47-54.

Lloret F. and Vilà M. 1997. Clearing of vegetation in Mediterranean garrigue: response after a wildfire. Forest Ecol. Manage. 93: 227-234.

Luis-Calabuig L., Tárrega R., Calvo L., Marcos E. and Valbuena L. 2000. History of landscape changes in northwest Spain according to land use and management. In: Trabaud L. (ed.), Life and Environment in the Mediterranean. WIT Press, Southampton, pp. 43-86.

Mallik A.U. and Gimingham C.H. 1983. Regeneration of heathland plants following burning. Vegetatio 53: 45-58.

Mapa de Suelos de Castilla y León 1988. Junta de Castilla y León. Consejería de Obras Públicas y Ordenación del Territorio. Dirección General de Medio Ambiente y Urbanismo.

Mazzoleni S. and Esposito A. 1993. Vegetative regrowth after fire and cutting of Mediterranean macchia species. In: Trabaud L. and Prodon R. (eds), Fire in Mediterranean Ecosystems. ECSC-EEC-EAEC, Brussels-Luxembourg, pp. 87-99.

Ministerio de Agricultura 1980. Caracterización agroclimática de la provincia de León. Dirección General de la Producción Agraria, Madrid.

Ministerio de Agricultura 1984. Mapa de cultivos y aprovechamientos de la provincia de León. Dirección General de Producción Agraria, Madrid.

Naveh Z. 1975. The evolutionary significance of fire in the Mediterranean Region. Vegetatio 29: 199-208.

Naveh Z. 1990. Fire in the Mediterranean - a landscape ecological perspective. In: Goldamer J.G. and Jenkins M.J. (eds), Fire in Ecosystems Dynamics. SPB Academic Publishing, The Hague, pp. 1-20.

Naveh Z. 1999. The role of fire as an evolutionary and ecological factor on the landscapes and vegetation of Mt. Carmel. J. Mediterr. Ecol. 1: 11-25.

Naveh Z. and Lieberman A.S. 1990. Landscape Ecology. Theory and Application. Springer-Verlag, New York.

Ne'eman G. and Goubitz S. 2000. Phenology of east Mediterranean vegetation. In: L. Trabaud (ed.), Life and Environment in the Mediterranean. WIT Press, Southampton, pp. 155-201.

Pausas J. 1999. Mediterranean vegetation dynamics: modelling problems and functional types. Plant Ecol. 140: 27-39. 
Tárrega R., Luis-Calabuig E. and Valbuena L. 2001. Eleven years of recovery dynamic after experimental burning and cutting in two Cistus communities. Acta Oecol. 22: 277-283. Terradas J. (ed.) 1996. Ecologia del foc. Edicions Proa S.A., Barcelona.

Trabaud L. 1987. Natural and prescribed fire: survival strategies of plants and equilibrium in Mediterranean ecosystems. In: Tenhunen J.D., Catarino F.M., Lange O.L. and Oechel W. (eds), Plant Response to Stress. Springer-Verlag, Berlin, pp. 607-621.

Trabaud L. 1995. Modalités de germination des cistes et des pins méditerranéens et colonisation des sites perturbés. Revue Ecologie, Terre et Vie 50: 3-14.

Trabaud L. 2000. Seeds: their soil bank and their role in postfire recovery of ecosystems of the Mediterranean basin. In:
Trabaud L. (ed.), Life and Environment in the Mediterranean. WIT Press, Southampton, pp. 229-259.

Trabaud L. and Lepart J. 1980. Diversity and stability in garrigue ecosystems after fire. Vegetatio 43: 49-57.

Valbuena L., Tárrega R. and Luis E. 1992. Influence of heat on seed germination of Cistus laurifolius and Cistus ladanifer. Int. J. Wildland Fire 2(1): 15-20.

Valbuena L., Tárrega R. and Luis-Calabuig E. 2000. Seed banks of Erica australis and Calluna vulgaris in a heathland subjected to experimental fire. J. Veg. Sci. 11: 161-166.

Vera M.L. and Obeso J.R. 1995. Regeneración del brezal atlántico de Cabo de Peñas después de un incendio severo. Stud. Oecol. 12: 223-236.

Webb N.R. 1998. The traditional management of European heathlands. J. Appl. Ecol. 35: 987-990. 